\title{
LINTASAN SEJARAH INDONESIA DALAM NOVEL-NOVEL SUPARTO BRATA
}

\author{
Yulitin Sungkowati \\ Balai Bahasa Surabaya,Jalan Siwalanpanji IIA, Buduran, Sidoarjo 61252 \\ Email: yulitins@yahoo.com
}

\begin{abstract}
This writing is aimed to discuss about Indonesian history that is described and interpreted by Suparto Brata in his novels, written in Indonesian and Javanese, mainly Sala Lelimengan (1965), Surabaya Tumpah Darahku (1978), November Merah (1984), Kremil (2002), Saksi Mata (2002), Donyane Wong Culika (2004), Gadis Tangsi (2004), Mencari Sarang Angin (2005), Kerajaan Raminem (2005), Dom Sumurup ing Banyu (2006), and Mahligai di Ufuk Timur (2007). The course of Indonesian history in the novels ranges from Dutch colonialism era up to new sociopolitical order era. If the formal history records famous person only (usually men only), the history of Suparto Brata's version presents the role and struggle of people from various social class, profession, gender, age, and the victims of Indonesian regime all with its humanistic perspective. Indonesian history is interpreted as the struggle against stupidity and betrayal of people who didn't learn from the past. The choice of using historical subject can be read and interpreted as an effort of the writer to question and ask readers to understand and appreciate the history of their nation as a meaningful thing, a valuable lesson for a better future.
\end{abstract}

\section{Key words}

Nation History, Literary Work, History Education

\section{Pendahuluan}

Sejak sebelum kemerdekaan, sastra Indonesia sudah mengenal novel-novel berlatar sejarah, seperti Suropati dan Robert Anak Suropati karya Abdul Muis serta Hulu Balang Raja karya Nur Sutan Iskandar. Pada era kemerdekaan, karya sastra berlatar sejarah umumnya mengambil peristiwa sejarah perang kemerdekaan sampai setelah tahun 1949-an. Pada tahun 1980-1990-an muncul karya-karya prosa Indonesia berlatar sejarah pula, antara lain Bumi Manusia, Anak Semua Bangsa, Jejak Langkah, dan Rumah Kaca karya Pramoedya Ananta Toer, Burung-Burung Manyar karya YB. Mangunwijaya, trilogi Ronggeng Dukuh Paruk karya Ahmad Tohari, serta Para Priyayi karya Umar Kayam. Selain Burung-Burung Manyar dan Para Priayi, pada umumnya karya-karya tersebut menggunakan latar waktu sezaman. Jika tetralogi Pulau Buru dan Burung-Burung Manyar ditempatkan dalam sejarah bangsa, ada waktu yang "kosong" beberapa periode karena tetralogi Pulau Buru hanya mengungkap era kolonialisme Belanda dan BurungBurung Manyar (meskipun merentang periode 1943-1979) tidak mengungkap masa Orde Lama dan Orde Baru. Kekosongan itu terisi oleh terbitnya Para Priayi yang mengungkap periode waktu tahun 1930-1967 (Mahayana, 2007:278-279) sehingga menggambarkan perjalanan "sejarah bangsa" yang relatif lengkap. Tiga tahun terakhir ini dunia sastra Indonesia juga diramaikan oleh munculnya novel-novel bertemakan sejarah dengan setting waktu yang lebih lampau, seperti serial Gajah Mada oleh Langit Kresna Hariadi, Dyah Pitaloka: Senja di Langit Majapahit karya Hermawan Aksan, Pangeran Diponegoro karya Remy Silado, Rahasia Meede: Misteri Harta Karun VOC karya E.S. Ito, dan Pelangi di Atas Glagahwangi karya S. Tidjab. 
Maraknya novel-novel bertemakan sejarah tersebut mengundang diskusi yang menarik di kalangan pengamat atau pelaku sastra dan sejarawan berkaitan dengan hubungan antara sastra dan sejarah. Kuntowijoyo (1987:127) mengemukakan bahwa objek karya sastra adalah realitas (apapun yang dimaksud dengan realitas oleh pengarang). Jika realitas yang dijadikan sebagai objeknya adalah peristiwa sejarah, karya sastra dapat: (1) mencoba menerjemahkan peristiwa itu dalam bahasa imajiner dengan maksud untuk memahami peristiwa sejarah menurut kadar kemampuan pengarangnya; (2) menjadi sarana bagi pengarangnya untuk menyampaikan perasaan, pikiran, dan tanggapannya mengenai suatu peristiwa sejarah; dan (3) merupakan penciptaan kembali sebuah peristiwa sejarah sesuai dengan pengetahuan dan daya imajinasi pengarangnya, seperti halnya dengan karya sejarah. Ketiga hal itu menunjukkan peran karya sastra sebagai simbol verbal, yaitu sebagai cara pemahaman (mode of comprehension), cara perhubungan (mode of communication), dan cara penciptaan (mode of creation). Ketiga peranan simbol tersebut dapat menjadi satu karena perbedaan-perbedaannya lebih merupakan asumsi teoretis yang sulit dipilah-pilah dalam penciptaan suatu karya sastra. Campur tangan dan motivasi pengarang yang membedakannya. Dalam karya sastra yang diciptakan sebagai cara pemahaman, kadar peristiwa sejarah sebagai aktualitas atau kadar faktisitasnya akan lebih tinggi daripada kadar imajinasi pengarang, sedangkan dalam karya sastra sebagai cara penciptaan kadar faktisitasnya lebih rendah daripada imajinasi pengarang. Dalam karya sastra sebagai cara perhubungan, faktisitas dan imajinasi pengarang sama kadarnya.

Meskipun realitas yang berupa peristiwa sejarah dapat menjadi objek karya sastra, tulisan sejarah dan sastra memiliki perbedaan dalam pengolahannya. Sejarawan tidak sebebas sastrawan dalam penggarapan bahan-bahan sejarah. Kuntowijoyo (1987:128-129) mengemukakan perbedaan pengolahan objek tersebut berdasarkan skala yang dibuat oleh Koestler. Pertama, sejarah memiliki tugas mengungkapkan hal-hal yang benar-benar terjadi dan kejadian sebagaimana adanya, sedangkan sastra mengungkapkan hal-hal yang dapat dipahami. Kedua, penulisan sejarah harus mengikuti prosedur tertentu, seperti teknik dalam penataan ruang dan waktu, sedangkan karya sastra tidak tunduk pada prosedur-prosedur atau metode-metode tertentu. Ketiga, sejarah cenderung menggunakan referential symbol dengan menunjuk secara lugas atau langsung ke objek, sedangkan sastra lebih bersifat multitafsir. Sementara itu, Mahayana (2009) memaparkan perbedaan sastra dan sejarah itu secara lebih rinci sebagai berikut: (1) sastra merekam masa lalu, mencatat masa kini, sedangkan sejarah merekan masa lalu, meramal masa depan; (2) sastra merekonstruksi secara subjektif, sedangkan sejarah merekonstruksi peristiwa secara objektif; (3) sastra menyusun struktur secara koheren, sedangkan sejarah menyusun peristiwa secara kronologis; (4) peristiwa yang disampaikan dalam sastra disesuaikan, sedangkan dalam sejarah peristiwa disajikan secara sistematik dengan kebutuhan cerita sesuai dengan prosedur; (5) dalam karya sastra, fakta bersifat fiksional, sedangkan dalam sejarah bersifat faktual; (6) fakta dalam karya sastra tidak harus dapat diverifikasi, sedangkan dalam sejarah fakta harus dapat diverifikasi; (7) fakta dalam sastra berada dalam keadaan serba, sedangkan dalam sejarah fakta berada dalam satu kemungkinan-kemungkinan benar atau salah; (8) sastra memanfaatkan imajinasi secara maksimal, sedangkan sejarah memanfaatkan imajinasi untuk merekonstruksi peristiwa secara sistematik, koheren, dan logis; (9) sastra mengangkat peristiwa individual yang berpengaruh besar, sedangkan sejarah mengangkat peristiwa besar; (10) sastra menyarankan pemaknaan dibalik peristiwa, sedangkan sejarah pemaknaan dibalik peristiwa dan dampaknya bagi masyarakat; (11) sastra bersifat multitafsir, sedangkan sejarah bersifat monotafsir; dan (12) bahasa sastra bersifat konotatif (implisit), sedangkan bahasa sejarah bersifat denotatif (eksplisit). 
Pembedaan tersebut dinilai kurang tepat oleh Ardan (2007) yang menolak anggapan bahwa sejarah berbeda dengan karya sastra dalam hal cara kerja, kebenaran, hasil keseluruhan, dan kesimpulannya. Perbedaan itu masih dapat diperdebatkan karena sebagaimana sastra, sejarah juga memerlukan imajinasi penulisnya agar dapat merekosntruksi masa lalu. Kebenaran dalam sejarah juga merupakan sesuatu yang bersifat relatif dan sejarah pun pada suatu sisi dapat memunculkan pertanyaan berkaitan dengan keakuratan datanya. Bahkan, dalam pandangan kaum postmodernis, sastra semakin dekat dengan sejarah karena keduanya terkait dengan narasi. Narasi sejarah memakai pembabakan, seperti awal, pertengahan, dan akhir sebagaimana dalam narasi sastra yang dikenal dengan istilah plot. Taufik Abdullah (Mahayana, 2009) mengemukakan bahwa sastra memang dapat memberikan pantulan-pantulan tertentu mengenai perkembangan pemikiran, perasaan, dan orientasi pengarangnya serta dapat memperlihatkan bagaimana bekerjanya suatu bentuk struktural situasi historis tertentu dari lingkungan penciptanya. Akan tetapi, tidak ada peristiwa sebagai bagian dari mata rantai sejarah yang dapat dikonstruksikan dari novel (baca sastra). Dengan kata lain, sastra tidak dapat dijadikan sebagai dokumen sejarah atau sumber utama penulisan sejarah karena pada dasarnya sastra adalah karya imajinatif, bukan karya historis.

Prinsip tersebut menjadi pegangan para pengamat/pelaku sastra. Meskipun terdapat kesamaan nama, tempat, waktu, dan suasana dengan peristiwa sejarah, realitas yang ada dalam karya sastra tidak identik dengan realitas objektif sehingga tidak dapat dipandang sebagai realitas sejarah yang sesungguhnya (Manuaba, 2002). Realitas yang ada dalam karya sastra itu telah melewati proses kreatif dan imajinatif serta penilaian seorang pengarang sehingga tidak dapat dilepaskan dari subjektifitasnya dalam menafsirkan atau memaknainya. Kelahiran karya sastra pada dasarnya merupakan kehendak seorang pengarang untuk merespon atau menanggapi sebuah situasi atau keadaan yang pernah ditatapnya dan dalam merespon itu, seorang pengarang tidak dapat melepaskan diri dari segala sesuatu yang telah ada dalam dirinya. Oleh karena itu, peristiwa sejarah dalam karya sastra harus dilihat dalam kerangka fungsi atau sifat hakikinya, bukan akurasi data atau ketepatan deskripsi melainkan pemberian makna pada suatu peristiwa dan eksistensi manusia. Novel bertemakan sejarah dapat membantu mengenalkan dan mengangkrabkan suatu masyarakat pada masa lalu bangsanya.

Dalam konteks diskusi sastra dan sejarah itulah, perlu dibicarakan novel-novel karya pengarang dwibahasawan dari Surabaya, Suparto Brata, yang hampir selalu menggunakan peristiwa sejarah sebagai objek atau latarnya, tetapi selama ini nyaris luput dari perhatian para pengamat sastra. Suparto Brata memiliki perhatian yang besar pada sejarah, khususnya pada peristiwa sejarah yang terjadi di Kota Surabaya, seperti peristiwa pertempuran 10 November 1945. Dalam novel November Merah (1984), yang diindonesiakan dari cerita bersambung "November Abang" (terbit pertama kali di majalah Jayabaya tanggal 7 September-16 Oktober 1965) dan Mencari Sarang Angin (2005a) Suparto Brata mengungkap perlawanan rakyat Surabaya dalam pertempuran heroik tersebut. Untuk "menyakinkan" pembaca, dia tampaknya merasa tidak cukup hanya menghadirkan tokoh-tokoh sejarah, seperti Bung Tomo, Gubernur Suryo, dokter Sugiri, Bung Karno, Jenderal Mallaby dalam November Merah (1984), sehingga melengkapinya dengan foto-foto dari buku sejarah resmi, seperti foto peristiwa perobekan bendera Belanda di atap Hotel Oranye/Yamato jalan Tunjungan. Dalam novel ini, batas antara nonfiksi dan fiksi dibaurkan sedemikian rupa. Perhatiannya terhadap pertempuran 10 November 1945 tidak lepas dari penghayatannya atas peristiwa tersebut dalam korelasinya dengan sejarah bangsa, yaitu bahwa tanpa ada pertempuran 10 November 1945 tidak akan ada Perang Kemerdekaan Indonesia. Negara Kesatuan Republik Indonesia akan dicapai melalui perundingan atau diplomasi, bukan 
dengan perang, sehingga terkesan sebagai hadiah dari Ratu Belanda (Brata, 2007b:15). Pandangan ini sejalan dengan tulisan Ricklefs (2005:438) yang mencatat bahwa Pertempuran 10 November merupakan titik balik bagi Belanda yang selalu menganggap bahwa kemerdekaan hanyalah keinginan segelintir elit tanpa dukungan rakyat. Peristiwa itu merupakan lambang pengorbanan dan persatuan rakyat demi kemerdekaan.

Jika beberapa sejarawan mulai melirik novel-novelnya sebagai bahan studi sejarah (novel Saksi Mata, Surabaya Tumpah Darahku, November Merah menjadi sumber sekunder studi sejarah Els Bogaerts dari NIOD dan novel Mencari Sarang Angin, Surabaya Tumpah Darahku serta Kremil menjadi sumber pelengkap penyusunan buku sejarah Orang-Orang Ambon di Surabaya, 19301945), sudah selayaknya pemerhati sastra menangkapnya sebagai tanda bahwa ada sesuatu yang berharga dalam novel-novelnya yang patut dibicarakan dengan perspektif sastra. Jika Mahayana (2007:278-279) merangkai "sejarah perjalanan bangsa" yang "lengkap" harus melalui karya tiga pengarang, dalam karya-karya Suparto Brata sudah dapat dilihat lintasan sejarah Indonesia yang relatih "lengkap", yaitu dalam novel "Sala Lelimengan"/SL (1965), Surabaya Tumpah Darahku/STD (1978), November Merah/NM (1984), Kremil/K (2002), Saksi Mata/SM (2002), Donyane Wong Culika/DWC (2004), Gadis Tangsi/GT (2004), Mencari Sarang Angin/MSA (2005), Kerajaan Raminem/KR (2006), Dom Sumurup ing Banyu/DSiB (2006), dan Mahligai di Ufuk Timur/MdUT (2007).

\section{Sejarah Bangsa dan Pergulatan Beragam Manusia}

Peristiwa sejarah yang menjadi objek atau melatari novel-novel Suparto Brata adalah sebagai berikut: SL (masa Agresi Militer Belanda I/1947); STD (zaman Pendudukkan Jepang di Surabaya); NM (Kedatangan Tentara Sekutu/Pertempuran 10 November di Surabaya); K (Pemberontakan G 30/S PKI/ 1965-1967); SM (zaman Pendudukan Jepang di Surabaya); DWC (Pemberontakan PKI tahun 1965); GT (zaman kolonialisme Belanda di Medan); MSA (masa kolonialisme Belanda-Pemberontakan PKI Madiun-Agresi Militer Belanda II/1935-1950); KR (Kedatangan Jepang/Peralihan kekuasaan dari Belanda ke Jepang); DSiB (masa Agresi Militer Belanda I/1948); dan MdUT (zaman Pendudukan Jepang di Bagelen-Solo). Jika dirangkaikan, kesebelas novel tersebut mencakup periode waktu tahun 1935 (tercatat dalam MSA) hingga akhir September 1967 (tertulis dalam K), yang meliputi masa kolonialisme Belanda, masa pendudukan Jepang, Perang Kemerdekaan/Revolusi (Pertempuran 10 November, Agresi Militer Belanda pertama dan kedua, Pemberontakan PKI Madiun), Orde Lama/Pemberontakan G 30 S/PKI, dan awal Orde Baru. Novel-novel tersebut tidak sekadar mengungkap peristiwa sejarah yang pernah terjadi di Indonesia sejak sebelum hingga sesudah kemerdekaan, tetapi juga menggambarkan perjuangan hidup manusia dari beragam kelas sosial, jenis kelamin, usia, dan profesi.

\section{Masa Kolonialisme Belanda}

Kolonialisme Belanda pada periode tahun 1927-1942 dalam sejarah Indonesia merupakan masa represi dan krisis ekonomi. Rezim Belanda memasuki masa yang paling menindas terhadap pribumi sehingga melahirkan perlawanan yang kuat: meskipun berbeda pendapat, para elit tokoh bangsa waktu itu memiliki satu kesepahaman, yaitu tidak mungkin lagi bekerja sama dengan Belanda. Nasionalisme menempati posisi ideologis yang paling berpengaruh (Ricklefs, 2005:374). Kartodirdjo (1984:13-14) juga mencatat abad ke-20 sebagai abad bangkitnya nasionalisme di kalangan penduduk jajahan di Indonesia yang secara tegas telah merumuskan satu tujuan, yaitu kemerdekaan. 
Dalam beberapa hal, novel-novel Suparto Brata merefleksikan kolonialisme Belanda yang berbeda dengan catatan dua sejarawan tersebut, sebagaimana terungkap dalam novel GT dan MSA. Kedua novel itu tidak secara jelas memosisikan Belanda sebagai musuh, tetapi justru sebagai sumber wacana untuk meningkatkan peradaban bangsa Jawa (baca Indonesia), dengan menggambarkan transformasi seorang rakyat biasa berperadaban rendah menjadi priayi berperadaban tinggi melalui proses pendidikan membaca dan menulis dengan "kiblat" pada kemajuan peradaban bangsa Belanda. Melalui pendidikan membaca dan menulis, Rokhayah berhasil meningkatkan martabatnya dari gadis kampung yang bodoh dan liar menjadi priayi terhormat. Perubahan hidup Rokhayah itu dioposisikan dengan nasib Turnadi dan Rokhim yang menjadi pengkhianat bangsa hingga hidupnya berakhir tragis. Materi sejarah dalam novel ini dimanfaatkan sebagai penyampai gagasan pentingnya peran pendidikan dalam upaya membangun hidup merdeka dan bermartabat.

Novel GT menggambarkan kehidupan pribumi, baik dari kelas wong cilik (keluarga Wongsodirjo dan penghuni tangsi lainnya) maupun bangsawan (kapten Sarjubehi) yang bekerja sebagai tentara Kompeni Belanda di tangsi militer Lorong Belawan, Medan. Akan tetapi, fokus novel ini tidak pada aktivitas tentara KNIL, melainkan pada perjuangan Teyi dan Raminem, anak dan istri Wongsodirjo serta para istri dan anak serdadu KNIL lainnya yang berasal dari Jawa. Dalam lingkungan yang liar dan serba kekurangan itulah, diperlihatkan bagaimana semangat Teyi mengubah hidupnya menjadi manusia berperadaban tinggi. Di bawah bimbingan Putri Parasi, Teyi mendapat pendidikan membaca, menulis, bahasa Jawa halus dan bahasa Belanda, serta sopan santun. Bekal pendidikan inilah yang mengendalikan hidup Teyi sehingga tidak terseret dalam kehidupan liar tangsi. Semangat dan cita-cita Teyi untuk membangun hidup yang bermartabat itu digambarkan tidak mendapat halangan dari Belanda atau Jepang, tetapi justru oleh Manguntaruh dan Dasiyun yang masih tergolong saudaranya. Dalam novel ini pun, oposisi menyangkut nasib orang-orang yang berpendidikan dan tidak berpendidikan sangat jelas dengan menempatkan keberhasilan hidup orang-orang yang mau belajar dan kegagalan hidup orangorang yang hidup dalam kebodohan.

\section{Masa Pendudukan Jepang (1942-1945)}

Masa pendudukan Jepang dalam catatan Ricklefs (2005:405) merupakan periode yang paling menentukan dalam sejarah Indonesia karena pemerintah militer Jepang mengindoktrinasi, melatih, dan mempersenjatai generasi muda serta memberi kesempatan kepada para pemimpin untuk berhubungan dengan rakyat di tingkat bawah. Meskipun sama-sama ingin menguasai Indonesia, Belanda memaksakan suatu ketenangan yang tertib, sedangkan Jepang memobilisasi rakyat. Dengan meminta bantuan pemimpin-pemimpin Indonesia, Jepang mempolitisasi dan memobilisasi rakyat hingga ke tingkat desa untuk kepentingan perang hingga menggoncang kehidupan desa yang apolitis pada zaman kolonial Belanda. Peniadaan pengaruh Belanda, baik dalam hal politik maupun budaya, membangkitkan kesadaran nasional yang lebih mantap. Berbagai kebijakan Jepang itulah yang memungkinkan atau mendorong lahirnya revolusi Indonesia menentang kehadiran kembali tentara Belanda setelah Jepang menyerah. Di samping kebijakan yang secara tidak langsung menguntungkan bangsa Indonesia, Jepang juga membuat kebijakan yang sangat menyengsarakan. Membanjirnya mata uang pendudukan membuat tingkat inflasi yang sangat tinggi, pengaturan pangan dan tenaga kerja secara paksa (romusha), gangguan transportasi, dan kekacauan umum mengakibatkan timbulnya kelaparan, kematian, dan kesengsaraan. 
Refleksi atas kehidupan bangsa Indonesia pada masa pendudukan Jepang dalam karya prosa Suparto Brata adalah gambaran masa-masa kegelapan karena kelaparan, ketakutan, dan kekejaman Jepang yang di luar batas perikemanusiaan, sebuah gambaran yang sangat kontras dengan masa pemerintahan kolonial Belanda yang tertib dan teratur. Penderitaan akibat pendudukan Jepang itu tidak hanya dirasakan oleh masyarakat kelas bawah atau wong cilik, tetapi juga oleh keluarga bangsawan, seperti Raden Ayu Rumsari dalam novel SM yang dipaksa menjadi budak nafsu/jugun ianfu seorang komandan Jepang bernama Ichiro. Raden Ayu Rumsari bersama suaminya, Wiradad, berjuang melalui gerakan bawah tanah untuk menghancurkan tentara Jepang yang telah merendahkan martabat bangsanya. Kematian RA. Rumsari membawa Kuntara yang baru berusia 13 tahun terlibat dalam perjuangan. Kuntara bekerja sama dengan Wiradad berhasil meledakkan gudang persenjataan Jepang yang berkedok pabrik karung. Peran anak-anak dalam perjuangan kemerdekaan menggambarkan bahwa nasionalisme bukan hanya milik orang dewasa.

Kekejaman Jepang juga tergambar dalam KR yang merupakan kelanjutan dari GT. Novel ini mengungkap kehidupan para penghuni tangsi saat kedatangan tentara Jepang. Kaum lelaki atau para serdadu KNIL dikirim oleh Belanda ke Tanjung Balai untuk melindungi kilang minyak dan membendung serangan tentara Jepang. Dalam patroli itu, sersan Wongsodirjo dibunuh oleh Manguntaruh yang ingin menguasai harta dan istrinya, Raminem. Setelah melewati perjalanan panjang melalui laut dan darat serta menyaksikan kekejaman Jepang, para istri serdadu KNIL itu tiba di kampung halamannya di Jawa. Dengan bekal pendidikan dari Putri Parasi dan uang yang dikumpulkan melalui kerja kerasnya selama di tangsi, Teyi dan Raminem berjuang membangun "kerajaan" di tengah kesulitan hidup akibat pendudukan Jepang di kampung halamannya, Ngombol. Keberhasilan Teyi membangun hidup yang bermartabat itu terpapar dalam MdUT: Teyi menjadi seorang priayi kaya dan menggunakan kekayaannya untuk menghidupi dan menolong sesamanya. Perjuangan hidup Teyi melalui pendidikan, kerja keras, hemat, dan sabar mampu membuat dirinya bertransformasi dari manusia bodoh menjadi manusia cerdas, dari wong cilik menjadi priayi, dan dari orang miskin menjadi hartawan. Keadaan yang sulit tidak mematahkan semangatnya untuk belajar dan bekerja keras mewujudkan mimpinya meraih hidup sebagai manusia bermartabat. Berbeda halnya dengan Manguntaruh dan Dasiyun yang tidak mau belajar dan bekerja keras, hidupnya bagai parasit yang senantiasa merongrong dan mengganggu usaha Teyi.

Dalam novel MSA, kedatangan tentara Jepang juga digambarkan telah mengubah Surabaya menjadi kota kere dan gembel, penduduknya harus antri beras dan minyak, serta selalu dalam siaga mendengarkan bunyi sirine tanda serangan udara. Dalam kondisi demikian, Turnadi memilih menjadi tentara Jepang atau kenpetai yang berarti memilih menjadi kaki tangan penjajah yang menindas bangsa sendiri. Ia tidak segan-segan membunuh Yayi dan Slamet, jurnalis dan pejuang yang mendedikasikan hidupnya untuk membebaskan bangsanya dari belenggu kolonialisme Belanda.

Jika dalam SM, KR, MdUT, dan MSA tokoh-tokohnya berasal dari etnis Jawa, STD menggambarkan perjuangan hidup komunitas etnis Ambon di Surabaya pada masa pendudukan Jepang. Kedekatan etnis Ambon dengan penguasa Belanda pada masa penjajahan Belanda membuat posisi komunitas Ambon selalu dicurigai sebagai mata-mata Belanda oleh Jepang dan dimusuhi oleh kaum pribumi etnis Jawa di Surabaya (Sugiarti, 2009:126). Penderitaan panjang komunitas Ambon dengan fokus pada keluarga Pastora tidak berhenti dengan kematian Pastora dalam siksaan tentara Jepang. Kedatangan tentara sekutu juga membawa bencana dan 
penderitaan yang tidak kalah menyakitkan berupa tindak pelecehan seksual: adik-adik Jootje diperkosa secara bergiliran oleh tentara GURKHA atau sekutu yang menyerbu rumahnya ketika ia sedang berusaha mencari obat untuk ibunya yang sakit. Rasa kebangsaan dan nasionalisme akhirnya mengalahkan sentimen kesukuan sehingga Jootje yang masih remaja mengajak ibu dan saudaranya tetap tinggal di Surabaya sebagai tanah airnya dan bersama-sama rakyat Surabaya berjuang mempertahankan kota dari pendudukkan tentara sekutu.

\section{Masa Revolusi Kemerdekaan (1945-1950)}

Pada awal kemerdekaan, bangsa Indonesia dihadapkan pada pertarungan-pertarungan sengit antarindividu dan kekuatan-kekuatan sosial yang saling bertentangan sehingga menjadi periode yang kacau balau. Bangsa Indonesia yang baru merdeka tidak hanya menghadapi Belanda yang ingin menjajah kembali, tetapi juga menghadapi elemen bangsa sendiri yang berebut pengaruh dan kekuasaan. Surabaya menjadi arena pertempuran yang paling hebat sehingga menjadi lambang perlawanan nasional. Pada tanggal 20 Juli 1947, Belanda melancarkan aksi polisional atau Agresi Militernya yang pertama dan berakhir dengan perjanjian Renville, yang salah satu hasil kesepakatannya adalah garis demarkasi. Beberapa tokoh bangsa yang tidak puas dengan hasil perjanjian itu, bergabung dengan komunis melancarkan pemberontakan di Madiun tanggal 18 September 1948. Peristiwa Madiun menjadi titik balik revolusi yang sangat penting karena mengkhianati revolusi kemerdekaan. Pada tanggal 18 Desember 1948, bangsa Indonesia harus menghadapi aksi polisional atau agresi militer Belanda yang kedua (Ricklefs, 2005:428-468),

Kekacauan masa revolusi kemerdekaan dalam perjalanan sejarah bangsa dapat dilihat dalam novel SL, DSiB, NM, dan MSA. NM menggambarkan berakhirnya masa pendudukan Jepang yang ditandai oleh kedatangan tentara Sekutu di Surabaya. Novel ini diawali oleh pengkhianatan Turnadi dengan cara menyerahkan Mohammad Delar ke Kenpetai. Mohammad Delar, yang hanya seorang sopir, mengira Nursalim telah menjebloskannya ke penjara Jepang karena ingin merebut istrinya. Kekalahan Jepang menyelamatkan Mohammad Delar dari penjara kenpetai sehingga ia bisa mencari orang-orang yang mencoba mencelakainya. Ketika berusaha mencari Nursalim, Mohammad Delar diberitahu bahwa istrinya telah dinikahi oleh Nursalim. Akan tetapi, ternyata Nursalim hanya bermaksud menyelamatkannya dari kejahatan Turnadi yang diam-diam ingin merebut istri Mohammad Delar. Turnadi adalah temannya yang semasa Jepang berpihak menjadi tentara Jepang, sedangkan Nursalim menjadi komandan TKR yang disegani anak buahnya karena gigih menolak kedatangan sekutu. Meskipun marah, Mohammad Delar tetap bergabung dalam kesatuan TKR yang dikomandoi Nursalim dalam pertempuran 10 November. Dengan menepiskan perselisihan pribadi, mereka bersama-sama berjuang sampai titik darah penghabisan: Mohammad Delar dan Nursalim gugur sebagai pahlawan.

Masa perang kemerdekaan atau agresi militer Belanda dari sisi dunia telik sandi 'mata-mata' terungkap dalam novel SL dan DSiB. DSiB menceritakan upaya Herlambang atau Hartono, seorang anggota Tentara Rakyat Indonesia, menerobos garis demarkasi dan menyusup ke wilayah Republik guna membongkar pengkhianat atau mata-mata musuh yang berkedok sebagai pejuang dengan cara menjadi pekerja di gudang senjata yang sudah dikuasai oleh pasukan Republik Indonesia. Dengan menyamar menjadi mata-mata sekutu, Herlambang berhasil mendapat logistik dari tentara Belanda sebagai bekal menyusup ke wilayah republik. Dalam misinya itu, ia bertemu putri bangsawan Surakarta, Ngestireni, yang juga menyusup ke wilayah republik untuk membongkar kejahatan saudara tirinya yang telah menjandikannya budak nafsu tentara Jepang hanya karena ingin menguasai hartanya. Herlambang dan Ngesthireni ternyata mencari orang yang sama, yaitu Raden Mas Yogyantara. Pada masa Jepang, RM. Yogyantara 
menjadi mata-mata Jepang dan ketika Jepang menyerah pada sekutu ia beralih menjadi matamata Belanda dan mengkhianati perjuangan bangsa sendiri.

Dunia spionase sebagai bagian dari perang revolusi juga tampak dalam SL yang mengungkap peran seorang jurnalis Surabaya mencari pengkhianat bangsa yang menyusup ke wilayah kekuasaan republik pada masa pemberlakuan garis demarkasi: Ing Sala, ing dhaerah Republik, dheweke nemoni omah kang wong-wonge dadi antheke Landa 'Di Sala, di daerah Republik, dirinya menemukan rumah-rumah yang orang-orangnya menjadi antek Belanda (Brata, 1965:57). Karena kemampuannya, Mohammad Bakhtiar diminta menuliskan pengalaman dan perjuangan spionase TKR bernama Letnan Baidowi yang gugur dalam pertempuran di Salatiga. Catatan Letnan Baidowi ternyata tidak hanya berisi kisah perjuangannya di garis depan, tetapi berisi surat yang mengungkap pengkhianatan Dondi Suherman hingga tentara republik kalah dalam pertempuran. Gambaran pengkhianatan oleh warga bangsa sendiri pada masa revolusi fisik juga terlihat dalam novel MSA melalui pengkhianatan kaum komunis dalam pemberontakan yang gagal di Madiun pada tahun 1948.

\section{Masa Orde Lama (Percobaan Demokrasi)}

Ricklefs (2005:471-508) mencatat masa percobaan demokrasi (1950-1957) dan masa demokrasi terpimpin (1957-1965) dalam alam kemerdekaan sebagai masa yang dipenuhi rentetan kegagalan para pemimpin bangsa dalam memenuhi harapan-harapan tinggi setelah tercapainya kemerdekaan. Dalam periode masa demokrasi terpimpin ini, bangsa Indonesia tidak hanya menghadapi masalah kemiskinan dan kebodohan, tetapi juga peristiwa percobaan kudeta yang gagal oleh kaum komunis atau yang dikenal dengan Gerakan 30 September 1965.

Dalam Kremil, Suparto Brata menggambarkan periode masa percobaan demokrasi itu dengan perjuangan kaum perempuan yang tersingkir sebagai korban peristiwa politik tahun 1948 dan 1965. Peristiwa September 1965 menjadi titik tolak petualangan Marini menuntut balas kematian orang tuanya. Sepulang sekolah, Marini mendapati rumahnya dalam keadaan kosong dan tanpa rasa curiga menuruti ajakan pamannya, Sugeng, ke tempat rapat Barisan Tani Indonesia (BTI) onderbouw PKI. Di tempat inilah Marini tahu bahwa seluruh keluarganya telah dibantai dan mayatnya dimasukkan ke dalam lubang sumur di samping rumahnya. Marini atau Suyati, seorang remaja SMA, terseret dalam petualangan memburu dan membongkar kejahatan anggota PKI yang telah membantai keluarganya. Dalam upayanya membongkar kejahatan Sugeng, Marini, yang menyamar menggunakan nama Suyati, bertemu dengan Draji, seorang polisi menantu bangsawan yang keluarganya juga menjadi korban keganasan PKI. Suyati dan Draji menyisir tempat-tempat yang diduga menjadi persembunyian Sugeng dari lokalisasi Silir (Solo) hingga Kremil (Surabaya). Pencarian Suyati dan Draji itu secara langsung juga mengungkap perempuan-perempuan korban peristiwa politik tersebut yang berjuang demi mempertahankan hidup dengan bekerja sebagai PSK atau Pekerja Seks Komersial di lokalisasi Kremil. Meskipun bekerja di bawah tekanan karena dianggap sebagai "sampah" masyarakat, para perempuan itu berusaha tegar dan tetap membuat hidupnya berarti, setidaknya bagi sesamanya di lokalisasi dan keluarganya di kampung.

Pengkhianatan dan kebodohan kaum komunis terpapar pula dalam novel DWC. Kasminta dan Jumilah adalah anak muda desa biasa yang terbujuk rayuan anggota PKI sehingga masuk dalam Barisan Tani Indonesia (BTI). Dalam pelariannya akibat pemberontakan komunis yang gagal di Madiun, Kasminta menyamar menjadi Susmanta tetapi tetap menggunakan cara-cara komunis untuk menyingkirkan orang-orang yang tidak seideologi dengannya. Den Darmin, bekas tentara 
yang telah berjuang menumpas pemberontakan PKI Madiun dibunuh secara keji di tengah sawah. Ia juga menggalang dan memprovokasi masa untuk mengeroyok bekas gurunya yang dianggap menentang kehadirannya. DWC secara jelas menggambarkan orang-orang komunis sebagai orang culika 'curang, jahat' yang selalu mencari cara untuk merongrong, mengkhianati perjuangan bangsa, dan selalu membuat kekacauan. Tokoh Suryaningsih di dalam Kremil secara tajam menggambarkan pengkhianatan kaum komunis pada periode akhir Orde Lama membuat bangsa Indonesia jatuh dalam situasi masa yang sangat buruk: "Tahun 1945 kita memproklamirkan diri sebagai bangsa yang beradab, tahun 1965 kita menjadi bangsa biadab" (Brata, 2002a:472).

\section{Masa Orde Baru Awal (1965-1975)}

Periode tahun 1965-1975 sebagai masa penciptaan Orde Baru dengan dukungan orang-orang yang ingin bebas dari kekacauan akibat percobaan kudeta yang gagal oleh PKI pada masa Orde Lama. Akan tetapi, kondisi penegakan hukum dan penegakan HAM tampaknya dinilai lebih baik pada masa pemerintahan kolonial Belanda (Ricklefs, 2005:594).

Gambaran kehidupan awal Orde Baru terlihat dalam novel Kremil yang secara jelas mencantumkan latar waktu tahun 1965-1967. Lokalisasi Kremil menjadi representasi keadaan awal Orde Baru yang sangat sulit dari sisi ekonomi dan kacau dari segi politik. Para perempuan desa korban peristiwa politik tahun 1948 dan 1965 berjuang mempertahankan hidup di Surabaya dengan bekerja sebagai pekerja seks komersial. Para pekerja seks komersial yang seringkali dimarginalkan sebagai sampah masyarakat itu diperlihatkan sebagai perempuan-perempuan tangguh yang dalam keterpurukannya tetap menunjukkan semangat untuk memberi arti pada lingkungan dan bangsanya. Tidak sedikit kontribusi yang diberikan oleh lokalisasi Kremil dan PSK-nya dalam pembangunan, meskipun, demi menjaga moral, sumbangan itu seringkali diingkari dan dinafikan.

Di samping menggambarkan para perempuan korban perubahan situasi politik akibat pemberontakan dan pengkhianatan kaum komunis, Kremil juga menggambarkan kekangan pemerintah Orde Baru terhadap kebebasan berpikir rakyatnya. Kekangan itu terlihat melalui tokoh orang tua Suryaningsih yang selalu mengatur dan mengontrol segala keinginan anaknya. Suryaningsih memilih menjadi PSK daripada dipaksa orang tuanya menjadi manusia munafik dengan menikahi laki-laki yang berkedudukan tinggi, tetapi berperilaku buruk: "Kremil ini dunia kebebasanku dan juga diriku milikku sendiri” (Brata, 2002a:96).

\section{Karya Sastra sebagai Sarana Pendidikan Sejarah Bangsa}

Telah dikemukakan sebelumnya bahwa tiga peranan simbol dalam karya sastra yang menggunakan materi sejarah tidak dapat dipisah-pisahkan secara tegas sehingga campur tangan dan motivasi pengaranglah yang membedakannya. Ketika menulis sastra Suparto Brata tidak berpretensi menulis karya historis, tetapi secara sadar menggunakan karya sastra sebagai media untuk menuangkan gagasan dan pikiran-pikirannya tentang sejarah bangsa (Untoro, 2006:29). Suparto Brata (dlm. Untoro, 2006:50) mengatakan bahwa kecelakaan terbesar bangsa Indonesia adalah tidak mengajari bagaimana mencintai membaca dan menulis kepada anak-anak sejak dini sehingga mereka tumbuh menjadi anak bangsa yang buta pengetahuan dan buta sejarah bangsanya serta tidak dapat hidup secara modern. Hal itu menggambarkan posisi pemerintah dan masyarakat yang kurang mempedulikan serta menghargai sejarah bangsanya (Djokosujatno, 
2002). Jika Indonesia ingin tampil sebagai bangsa modern, pendidikan membaca dan menulis harus dibudayakan sejak dini, tidak hanya diajarkan di perguruan tinggi menjelang pembuatan skripsi. Dengan membaca buku, bangsa Indonesia akan mempelajari sejarah dan segala ilmu pengetahuan yang penting untuk mencapai kehidupan yang lebih baik, kehidupan yang berperadaban dan bermartabat (Brata, 2007c). Sejarah berhutang pada budaya tulis karena pengalaman atau peristiwa penting yang pernah dilihat, dialami, dan dirasakan manusia akan hilang jika tidak dituliskan atau didokumentasikan serta tidak akan dapat dibaca dan dipelajari oleh generasi selanjutnya, dan sebaliknya, tanpa membaca buku, bangsa Indonesia tidak akan mempelajari sejarahnya.

Hidup suatu bangsa akan mapan jika menempatkan sejarah pada posisi yang penting dalam pembangunan bangsa karena sejarah memiliki tiga dimensi waktu, yaitu masa lalu, masa kini, dan masa depan. Bangsa yang tidak mau belajar sejarah akan selalu seperti bayi baru lahir, tidak memiliki dimensi masa lalu sehingga harus selalu mengawali hidup dari titik nol. Dalam tulisan "Donyane Wong Culika Jilid II", Suparto Brata (2007b:16-18) mengatakan bahwa hingga saat ini bangsa Indonesia masih tergolong bangsa primitif karena kiat hidupnya hanya dari melihat dan mendengar, sebagaimana kodratnya. Tidak seperti melihat dan mendengar yang bersifat kodrati, membaca dan menulis tidak mungkin dapat dikuasai manusia tanpa diajarkan, dibiasakan, dan dibudayakan.

Weruh lan krungu kuwi kodrat, dene maca lan nulis kuwi kawruh panguripan. Mula maca lan nulis kuwi kudu disinau, diajarake, diwulangake, diwuruki, digladhi, dikulinakake, dilantipake, lan dibudayakake (Brata, 2005c)

'Melihat dan mendengar itu kodrat, adapun membaca dan menulis itu ilmu kehidupan sehingga membaca dan menulis itu harus dipelajari, diajarkan, dilatih, dibiasakan, dan dibudayakan'

Pada masa pemerintahan kolonial Belanda dan pendudukan Jepang, pendidikan membaca dan menulis sudah diberikan sejak sekolah rakyat, tetapi ketika Indonesia merdeka, terutama pada era Orde Baru, anak sekolah tidak pernah diajari membaca dan menulis lagi sehingga bangsa Indonesia menjadi bangsa yang bodoh, primitif, dan semakin jauh tertinggal dari bangsa-bangsa modern. Keinginan untuk mengenalkan dan membuka mata generasi muda agar memahami dan menghargai sejarah bangsanya itulah yang memotivasi Suparto Brata menggunakan materi sejarah dalam karya prosanya. Ia berharap bangsa Indonesia mendapat pelajaran "sejarah bangsa" dari pengalaman dan penghayatan hidupnya selama tiga zaman. Dengan bingkai sejarah, novel-novel Suparto Brata mencoba memperlihatkan perbedaan nasib orang-orang yang mau belajar dan orang-orang yang tidak mau belajar.

Tokoh Rokhim (MSA), Kasminta dan Jamilah (DWC), Turnadi (NM), Sugeng dan Herman (Kremil), Manguntaruh dan Dasiyun (GT, KR, dan MdUT), Dondi Suhirman (SL), dan Raden Mas Yogyantara (DSiB) mewakili gambaran manusia yang tidak mau belajar sehingga hidupnya berakhir tragis. Orang-orang komunis seperti Rokhim, Kasminta, Sugeng, dan Herman terlibat dalam gerakan 30 S/PKI pada tahun 1965 karena tidak belajar sejarah bahwa pemberontakan komunis pada masa lalu (peristiwa Madiun 1948) telah gagal. Kebodohan Turnadi, Rokhim, Kasminta, Dondi Suherman, Yogyantara, Manguntaruh, dan Dasiyun membuat mereka tidak dapat membedakan perbuatan yang benar dan salah sehingga memilih menjadi kaki tangan musuh, menjadi antek-antek penjajah, melemahkan, dan menggerogoti perjuangan bangsa 
sendiri. Akibat kebodohan mereka, ribuan nyawa tidak berdosa harus mati sia-sia dan ribuan orang lainnya hidup dalam penderitaan. Tokoh-tokoh tersebut juga nasibnya berakhir tragis.

Di sisi lain, tokoh-tokoh yang mau belajar membaca dan menulis, seperti Teyi (GT, KR, MdUT) dan Rokhayah (MSA) dapat meningkat martabat hidupnya, tinggi rasa kemanusiaannya, menjadi pemimpin di lingkungannya, tidak mudah dihasut untuk mengkhianati perjuangan bangsa sendiri, dan dapat membedakan perbuatan baik atau buruk sehingga tidak terjebak pada putaran nasib yang sama. Pendidikan menjadi kunci transformasi ke arah hidup yang lebih baik.

Akan tetapi, sering kali tokoh-tokoh yang potensial itu justru mati di tangan orang-orang culika 'curang, jahat' yang masih banyak di negeri ini. Suparto Brata mengemukakan istilah nekrofilia dalam DWC untuk menggambarkan bangsa Indonesia. Dalam sebuah percakapannya dengan Pratinah, Steffie Tjia (pejuang dari etnis Tionghoa yang dibantai komunis hanya karena pernah menempuh pendidikan kedokteran di Amerika) mengatakan bahwa, "Bangsa Indonesia ini adalah bangsa nekrofilia, yaitu berpotensi membangun, tetapi digerogoti oleh kekuatan bangsa sendiri". Den Darmin, seorang bekas tentara yang pernah terlibat dalam operasi penumpasan pemberontakan PKI Madiun tetapi kemudian memilih pensiun dini dan berjuang dengan cara memberi bimbingan kepada para petani di desa agar dapat meningkatkan produktivitas pertaniannya serta mengajarkan sastra agar meningkat rasa kemanusiaannya, dibunuh secara keji oleh anggota komunis. Steffie Tjia dan Den Darmin merupakan contoh korban nekrofilia.

\section{Penutup}

Dari sebelas novel yang telah dibicarakan dapat ditarik suatu benang merah bagaimana "sejarah bangsa" ditafsirkan oleh Suparto Brata, yaitu perjuangan hidup berbagai elemen bangsa: lakilaki-perempuan, wong cilik-bangsawan, tentara, jurnalis, sopir, orang dewasa, dan anak-anak yang tidak hanya harus berhadapan dengan musuh asing (baca penjajah), tetapi juga rongrongan dari saudara sebangsa. "Sejarah bangsa" juga ditafsirkan sebagai sejarah kebodohan dan pengkhianatan yang dilakukan oleh orang-orang yang tidak mau belajar dari masa lalu dan membaca sejarah bangsanya. Secara implisit hal itu menyiratkan pemikiran pengarang bahwa musuh terbesar bangsa Indonesia dari dulu hingga kini sesungguhnya bukan Belanda, Jepang, Inggris atau sekutu, atau bangsa lainnya, tetapi kebodohan. Kebodohan telah menjerumuskan bangsa Indonesia menjadi bangsa nista yang hidup dalam penjajahan bangsa lain selama berabad-abad pada masa lalu. Kebodohan juga yang membuat bangsa Indonesia di era kemerdekaan kini tetap terpuruk dan tertinggal jauh dari bangsa-bangsa "modern". Oleh karena itu, perjuangan melepaskan diri dari penjajahan bangsa lain itu memang penting, tetapi yang tidak kalah penting adalah perjuangan memerdekakan diri dari kebodohan, dari kebutaan baca tulis, dan kebutaan sejarah. Secara politik, bangsa Indonesia memang sudah mencapai kemerdekaannya, tetapi secara kultural masih hidup dalam alam kebodohan sehingga bangsa Indonesia harus berjuang lebih keras lagi untuk membebaskan diri dari belenggu kebodohan.

Sebagaimana Nevins (Sugihastuti, 2007:161) yang mengatakan bahwa sejarah dapat menjadi cermin untuk melihat masa sekarang dan menjadi pedoman untuk menata masa depan, Suparto Brata pun tampaknya mencoba mengatakan bahwa masa lalu itu penting sebagai cermin untuk melangkah ke depan agar apa yang buruk di masa lalu tidak terulang lagi. Melalui novelnovelnya, ia berupaya membantu mengenalkan dan mengakrabkan masyarakat pada masa lalu bangsanya dengan harapan dapat menanamkan akar yang kuat sebagai landasan untuk merumuskan dan menata masa depan yang lebih baik. Karya prosa Suparto Brata ini barangkali dapat dijadikan sebagai semacam wacana alternatif tentang sejarah bangsa. 


\section{DAFTAR PUSTAKA}

Ardan, Asvi Warman.2006. "September, antara Sastra dan Sejarah". Dalam Kompas, 30 September

Brata, Suparto. 1965. "Sala Lelimengan: Roman Zaman Perjuangan". Surabaya. Tidak diterbitkan. .1978. Surabaya Tumpah Darahku. Surabaya: CV. Surya Kencana .1984. November Merah. Surabaya: Bina Ilmu .2002a. Kremil. Yogyakarta: Pustaka Pelajar .2002b. Saksi Mata. Jakarta: Kompas .2004. Donyane Wong Culika. Yogyakarta: Narasi .2004. Gadis Tangsi. Jakarta: Kompas .2005. Mencari Sarang Angin. Jakarta: Grasindo .2005b. "Sastra Jawa, Secercah Pengalaman". Dalam Kompas Jawa Timur, Tanggal 24 September .2005c. "Hadiah Sastra Pangastuti". Dalam Djoko Lodang, No. 41 Tahun ke-34, Sabtu, 12 Maret .2005d. "Hadiah Sastra Pangastuti". Dalam Djoko Lodang, No. 42 Tahun ke-34, Sabtu, 19 Maret .2006. Kerajaan Raminem. Jakarta: Kompas .2006. Dom Sumurup ing Banyu. Yogyakarta: Narasi .2007a. Mahligai di Ufuk Timur. Jakarta: Kompas .2007b. "Biodata Suparto Brata dan Beberapa Kegiatannya Akhir-Akhir ini Menuju The S.E.A. Write Awards 2007. Surabaya. Tidak diterbitkan.

Djokosujatno, Apsanti. 2002. "Novel Sejarah Indonesia: Konvensi, Bentuk, Warna, dan Pengarangnya". Dalam Makara, Sosial Humaniora, Vol. 6, No. 1, Juni 2002, hlm. 1419.

Kartodirdjo, Sartono, 1984. Pemberontakan Petani Banten 1988. Jakarta: Pustaka Jaya Kuntowijoyo. 1987. Budaya dan Masyarakat. Yogyakarta: Tiara Wacana.

Mahayana, Maman S. 2007. Ekstrinsikalitas Sastra Indonesia. Jakarta: Radja Grafindo Persada .2009. "Fakta dan Fiksi: Pertalian Sastra dan Sejarah". Diunduh dari http://www.mahayana-mahadewa.com, 18 April 2009

Manuaba, Putera.2002. "Spirit Sejarah dalam Karya Pramoedya Ananta Toer". Makalah Seminar Realitas Sejarah dalam Karya Sastra. Universita Airlangga, Surabaya, Tanggal 16 Desember 2002

Ricklefs,M.C. 2005. Sejarah Indonesia Modern 1200-2004. Jakarta: Serambi Ilmu Semesta Sugiarti, Eni. 2009. Orang-Orang Ambon di Surabaya, 1930-1945. Yogyakarta: Eja Publisher. 
Sugihastuti. 2007. Teori dan Apresiasi Sastra. Cet. II. Yogyakarta: Pustaka Pelajar.

Untoro, Ratun. 2006. "Pemikiran Suparto Brata dalam Karya-Karya Sastranya". Tesis. Yogyakarta: Universitas Gadjah Mada. 